\title{
Migração e educação: analisando o cotidiano escolar na Região Metropolitana do Rio de Janeiro
}

\section{Resumo}

O objetivo deste texto é apresentar os primeiros resultados de uma pesquisa que busca descrever e analisar a inserção escolar de migrantes/imigrantes e/ou descendentes de migrantes/imigrantes estabelecidos na Região Metropolitana do Rio de Janeiro, investigando se tais processos podem acarretar inclusão ou exclusão e também sua adaptação às transformações da sociedade abrangente. Esta investigação se propõe realizar uma pesquisa básica de análise qualitativa e de caráter descritivo, que se fará por meio de revisão de literatura, análise de documentos normativos e de fontes bibliográficas primárias e secundárias, bem como de observação participante, de entrevistas a serem realizadas com os alunos, pais, equipe técnica e professores de escolas da Baixada Fluminense, e de questionários a aplicar. São os primeiros resultados de um projeto amplo, mas é possível sinalizar que migrantes, ou seus filhos, quando passam a frequentar a escola, entram, rotineiramente, em choque com os valores, comportamentos e informações que lhes são apresentados. Observamos, também, que ainda são muito poucos os estudos sobre a socialização primária de migrantes e imigrantes e as relações sociais dentro da escola.

Palavras-chave: Educação; Culturas e Identidades.

\section{Miriam de Oliveira Santos} Doutora em Antropologia pela Universidade Federal do Rio de Janeiro. Professora da Universidade Federal Rural do Rio de Janeiro - Brasil. mirsantos@uol.com.br

\section{Para citar este artigo: \\ SANTOS, Miriam de Oliveira. Migração e Educação: analisando o cotidiano escolar na Região \\ Metropolitana do Rio de Janeiro. Revista PerCursos. Florianópolis, v. 15, n.28, p. 95 - 119. jan./jun. 2014.}




\title{
Migration and education: analyzing everyday school life in the Metropolitan Area of Rio de Janeiro
}

\begin{abstract}
The objective of this paper is to present the first results of a research that aims to describe and analyze the school integration of migrant / immigrant and / or descendants of migrants / immigrants in the metropolitan area of Rio de Janeiro, investigating whether such processes can lead inclusion or exclusion and also its adaptation to the larger society. This research proposes to perform a basic search, the qualitative analysis, descriptive, that will be through literature review, analysis of normative documents and primary and secondary literature sources, as well as participant observation, interviews and questionnaires to be conducted with students, parents, teachers and technical staff from schools in Baixada Fluminense. Are the first results, even partial, of a large project but, it is possible to signal that, when immigrants or their children go to school, routinely clash with the values, behaviors and information presented to them. We also note that they are still very few studies on the primary socialization of migrants and immigrants and the social relations within the school.
\end{abstract}

Keywords: Education. Cultures and Identities. 
Nosso problema de pesquisa é a recepção do migrante e/ou seus descendentes na escola e sua percepção a respeito dela. Buscamos investigar como se dá o acolhimento e se existem diferenças de tratamento em relação a migrantes de diferentes estados da Federação. Este é um recorte de uma pesquisa maior, que busca investigar a inserção, o acolhimento e a socialização de migrantes, imigrantes e seus descendentes nas instituições de ensino brasileiras. ${ }^{1}$

Priorizando as investigações sobre a socialização primária e as relações sociais dentro da escola, enfocaremos, de modo especial, as relações dos migrantes e/ou seus descendentes com os professores e demais alunos.

Formam o contexto empírico da pesquisa duas escolas de ensino médio, uma de ensino fundamental e uma de educação infantil em um município da Região Metropolitana do Rio de Janeiro. Nas escolas de ensino médio foram entrevistados alunos, funcionários e professores, além da observação participante e das entrevistas e questionários com pais, equipe técnica e professores. São resultados ainda parciais de um projeto amplo; contudo, é possível sinalizar que, quando migrantes ou seus filhos passam a frequentar a escola, entram, rotineiramente, em choque com os valores, comportamentos e informações que lhes são apresentados. Observamos também que ainda são muito poucos ${ }^{2}$ os estudos no Brasil sobre a socialização primária de migrantes e imigrantes e as relações sociais dentro da escola.

A migração é uma categoria multidisciplinar. Toda migração envolve mudanças e uma multiplicidade de rupturas de laços familiares, de grupos de pertinência, de costumes, valores, cultura, de relação de produção, dentre outros, e são essas transformações e rupturas que forjam as características do processo migratório (SAYAD, 1998).

O senso comum sobre a imigração e, especialmente, a literatura nacionalista costuma pressupor que, quando os imigrantes abandonam seu país de origem e se fixam

\footnotetext{
${ }^{1}$ O projeto de pesquisa Migração e educação: Socialização de Filhos de Migrantes/Imigrantes na Sociedade Globalizada começou a ser desenvolvido em maço de 2013 e é financiado pelo CNPq e pela Faperj.

2 São mais comuns os trabalhos sobre descendentes de imigrantes, nesse sentido ver, por exemplo: André, 2007; Gusmão, 2005, Kosminsky, 2000; Yang, 2011. A Revista Interdisciplinar de Mobilidade Humana lançou em junho de 2014 um número especial sobre o tema.
} 
em outro, eles abandonam completamente os vínculos com tudo aquilo que deixaram para trás. No máximo, aceita-se que eles ainda vão continuar falando sua língua e comendo ao menos alguma coisa de sua comida por alguns anos e manter uma contínua nostalgia do passado. Esta ideia tem algum fundo de verdade, pois a grande maioria, ao chegar a um novo país, está mais preocupada em conquistar alguma segurança econômica e sobreviver na nova realidade do que com qualquer outra coisa. Isto não significa, porém, que deixem de ser o que eram antes de imigrar. A língua, a maneira de ver o mundo, os hábitos e outras coisas adquiridas na infância e na juventude continuam com os imigrados e não se perdem no processo de migração.

Schutz (1971) ressalta que a aquisição da linguagem é o passo mais importante no processo de adaptação de um estrangeiro ou de um novato ao grupo. Acrescentaríamos que mesmo migrantes internos têm necessidade de uma adaptação ao linguajar do lugar de destino. Este autor enfatiza o papel da linguagem como esquema de interpretação do mundo, salientando que o papel emocional da linguagem é o mais difícil de ser aprendido pelo estrangeiro. Schutz acredita que a aquisição de uma linguagem ou idioma só é completa quando este aspecto emocional foi internalizado. Por isso, em sua opinião, alguém só “domina inteiramente um idioma como instrumento de expressão se for capaz de, nesta língua, escrever cartas de amor, rezar e praguejar, além de saber dizer coisas com os matizes e nuances nas situações adequadas" (SCHUTZ, p. 1.001).

Como crianças e adolescentes adquirem mais rapidamente estas competências linguísticas do que seus pais, é comum, em famílias de imigrantes, que a língua seja utilizada pelos jovens como sinal de rebeldia e de desafio à autoridade deles. No caso de imigrantes internos, estigmatizados em função de sua origem regional, encontramos frequentemente adolescentes que se envergonham do sotaque de origem.

Ferreira (1999) demonstrou que no Brasil, onde, a partir da década de 1950, predominou a migração interna, sua representação está conectada diretamente ao fluxo campo-cidade e, principalmente, Nordeste-Sudeste, elegendo o nordestino como o representante emblemático do migrante brasileiro. O fenômeno das grandes correntes migratórias internas em nosso País tem uma longa história, ilustrada seja na literatura, na música e no folclore, seja nos registros de alguns historiadores. 
Ainda de acordo com o mesmo autor, apesar da presença significativa de imigrantes externos em grandes centros como São Paulo e Rio de Janeiro, a presença da dicotomia campo-cidade assume maior expressão, sendo mais forte a representação do migrante do interior. Seu lugar de deslocado parece mais acentuado no espaço urbano, já que aí observamos um maior confronto representacional à medida que as rupturas presentes em suas vivências se chocam de forma muito intensa com a polissemia das metrópoles, por sua complexidade assustadora em termos de comunicação, regras e ordenações espaciais e linguísticas, tornando seu drama mais crítico, podendo assumir uma expressão mais intensa e sofrida (FERREIRA, 1999).

Quando os imigrantes, ou seus filhos, passam a frequentar a escola, rotineiramente entram em choque com os valores, comportamentos e informações que Ihes são apresentados. Além disso, quanto mais instruído é o filho, maiores as diferenças entre os próprios valores e os deu seus pais. Bourdieu afirma que tais diferenças afetam também as relações de poder, já que existem arranjos familiares em que "o pai analfabeto é obrigado a recorrer ao filho ou filha, ainda meninos, para ler ou redigir cartas, preencher formulários administrativos ou até orientar suas decisões pelo que diz respeito à vida econômica da família" (BOURDIEU, 1979, p. 74).

Sendo assim, a escola, ao mesmo tempo em que propicia inserção e adaptação para aos filhos, também pode ser uma fonte de conflitos na medida em que suas orientações não coincidem com as expectativas dos pais.

\section{O cotidiano escolar}

O cotidiano escolar e o trabalho docente passaram por um processo de mudanças significativas ao longo do século XX; configuram uma realidade marcada contraditoriamente por rupturas e continuidades. É possível verificar, no bojo desse processo, a crescente importância atribuída aos aspectos subjetivos da educação e do trabalho docente.

Segundo Konder (2006, p. 20), “Marx lembra que o educador também é educado: antes de exercer a sua influência formadora, ele próprio é formado pelo sistema no qual 
está inserido". Afirma ainda que o educador, no diálogo com seus alunos, transmite não apenas conhecimentos, mas também convicções (KONDER, 2006, p. 20). Tais afirmações respaldam a importância de estudar os aspectos subjetivos do ensino, o contexto onde estão inseridos os professores, as relações interpessoais, seus valores e suas convicções religiosas.

Lembramos Claparède (1973), para quem a "educação sob medida" é o sonho de todos os que acham absurdo ensinar a mesma coisa no mesmo momento, com os mesmos métodos, a alunos diferentes. Concordamos com Emilia Ferreiro, quando afirma:

A escola pública, gratuita e obrigatória do século XX é herdeira da do século anterior, encarregada de missões históricas de grande importância: criar um único povo, uma única nação, anulando as diferenças entre os cidadãos, considerados como iguais diante da lei. A tendência principal foi equiparar igualdade a homogeneidade. Se os cidadãos eram iguais diante da lei, a escola devia contribuir para gerar estes cidadãos, homogeneizando as crianças, independentemente de suas diferentes origens. Encarregada de homogeneizar, de igualar, esta escola mal podia apreciar as diferenças (FERREIRO, 2001, p. 6).

Sabendo disso, questionamos: como a escola, homogeneizadora por princípio e definição, lida com as diferenças? Ao enfatizar que a negação da diferença caracteriza uma primeira etapa da democratização do ensino, Ferreiro relembra também que nos tempos atuais a escola passa da diversidade negada a uma diversidade inevitável, mas pensada como indesejada. No fim do artigo, ela assinala que é fundamental "transformar a diversidade conhecida e reconhecida em uma vantagem pedagógica" (FERREIRO, 2001, p. 10).

Nos debates atuais na área da educação, o multiculturalismo surge como uma resposta tanto à imigração, quanto às novas identidades políticas e sociais. Hibridismo, diversidade étnica e racial, novas identidades políticas e culturais: estes são termos diretamente relacionados ao conceito, ambíguo e cambiante, de multiculturalismo.

No entanto, não podemos esquecer que o multiculturalismo é ao mesmo tempo um corpo teórico e um campo político. Segundo autores como Semprini (1999) e Grant 
(2000), por remeter à necessidade de se compreender a sociedade como um conjunto de identidades plurais, com base em diversidade de raças, gênero, classe social, padrões culturais e linguísticos, habilidades e outros marcadores identitários, o multiculturalismo constitui uma ruptura epistemológica com o projeto da modernidade, que acreditava na homogeneidade e na evolução "natural" da humanidade rumo a um acúmulo de conhecimentos que levariam à construção universal do progresso.

Segundo Hall:

As velhas identidades, que por tanto tempo estabilizaram o mundo social, estão em declínio, fazendo surgir novas identidades e fragmentando o indivíduo moderno, até aqui visto como um sujeito unificado. A assim chamada "crise de identidade" é vista como parte de um processo mais amplo de mudança, que está deslocando as estruturas e processos centrais das sociedades modernas e abalando os quadros de referência que davam aos indivíduos uma ancoragem estável no mundo social (HALL, 2006, p. 7).

Contudo, não devemos esquecer que para Hall:

[... ] a identidade é realmente algo formado ao longo do tempo, através de processos inconscientes, e não algo imanente, existente na consciência no momento do nascimento. Existe sempre algo 'imaginário' ou fantasiado sobre sua unidade. Ela permanece sempre incompleta, está sempre 'em processo', sempre "sendo formada" [...] (HALL, 2003, p. 38).

Por outro lado é necessário levar em conta que o projeto multicultural se insere em uma visão pós-moderna de sociedade, em que a diversidade, a descontinuidade e a diferença são percebidas como categorias centrais. Da mesma forma, contrapondo-se à percepção moderna e iluminista da identidade como essência estável e fixa, o multiculturalismo percebe-a descentrada, múltipla, em um permanente processo de construção e reconstrução. 
É importante distinguir os conceitos de diversidade cultural e multiculturalismo. A diversidade cultural sempre existiu, já que pouquíssimas sociedades humanas podem ser consideradas totalmente homogêneas; contudo, a ênfase política das diferenças culturais data da intensificação dos processos de globalização econômica e também das migrações.

A Organização das Nações Unidas para a Educação, Ciência e Cultura (UNESCO) aprovou, em 2001, a Declaração Universal sobre a Diversidade Cultural, documento no qual a cultura é compreendida como:

[...] conjunto dos traços distintivos espirituais e materiais, intelectuais e afetivos que caracterizam uma sociedade ou um grupo social e que abrange, além das artes e das letras, os modos de vida, as maneiras de viver juntos, os sistemas de valores, as tradições e as crenças (UNESCO, 2001, s/p).

Acerca da diversidade cultural, o mesmo documento indica:

A cultura adquire formas diversas através do tempo e do espaço. Essa diversidade se manifesta na originalidade e na pluralidade de identidades que caracterizam os grupos $\mathrm{e}$ as sociedades que compõem a humanidade. Fonte de intercâmbios, de inovação e de criatividade, a diversidade cultural é, para o gênero humano, tão necessária como a diversidade biológica para a natureza. Nesse sentido, constitui o patrimônio comum da humanidade e deve ser reconhecida e consolidada em beneficio das gerações presentes e futuras (UNESCO, 2001, s/p).

Observa-se, quanto ao conceito de multiculturalismo, ser um termo ambíguo. Embora usado para designar o fato de as sociedades serem compostas por grupos culturalmente distintos, também se aplica a uma política que visa à coexistência pacífica entre grupos étnica e culturalmente diferentes. O debate sobre as diferenças culturais e as formas de lidar com ela começa nos EUA, principalmente a partir dos estudos sobre imigrantes e sua inserção na cultura norte-americana. Após os anos 70 do século XX, espalha-se pelo mundo, criando uma corrente europeia quando as discussões acerca do 
multiculturalismo acompanham os debates sobre o pós-modernismo e sobre os efeitos da pós-colonização no mundo contemporâneo,

Considerando-se a polissemia do termo multiculturalismo e suas diversas abordagens, é importante salientar que, em sua vertente mais crítica, também denominada multiculturalismo crítico, ou perspectiva intercultural crítica (CANEN, 1999, CANEN e MOREIRA, 2001; MCLAREN, 2000), se busca ir além da valorização da diversidade cultural em termos folclóricos ou exóticos [aquele que, segundo Stuart Hall, 2003, "celebra a diferença sem fazer diferença"], para questionar a própria construção das diferenças e, por conseguinte, dos estereótipos e preconceitos contra os que são percebidos como "diferentes" no seio de sociedades desiguais e excludentes.

O debate sobre o multiculturalismo obriga também a redefinir o conceito de cultura, sobretudo a alargá-lo para aí incluir um conjunto de diferenças comportamentais. Atualmente, as culturas são vistas como representações construídas pela história, suscetíveis de mudanças em função das reivindicações dos vários grupos sociais.

Diversos países como Brasil, Portugal, Espanha e Canadá têm adotado o multiculturalismo na educação. No entanto, como demonstram Gusmão (2005) e André (2007), ao estudar respectivamente as escolas de Portugal e Espanha, a inserção dos imigrantes e seus filhos nos sistemas educacionais ainda é um desafio.

O pensamento multicultural tem perpassado vários discursos no campo educacional como tentativa de solucionar problemas cotidianos surgidos na prática docente. Esta corrente de pensamento se traduz em movimentos que buscam valorizar os padrões culturais dos diferentes grupos que compõem a população escolar.

[...] ao mesmo tempo, enfatizam a necessidade de adoção de medidas de reparação a injustiças e preconceitos com relação a identidades culturais, raciais, étnicas, de gênero e outras marginalizadas nos processos sociais, nos quais se inclui a educação (CANEN e XAVIER, 2011, p. 336). 
O lugar de trabalho do professor permite um constante contato com elementos culturais da comunidade na qual a escola está inserida, tais como vestimentas, gestualidade, sotaques, músicas, expressões religiosas, etc. Tal pluralidade cultural pode ser vista como um aliado do trabalho docente, ou até como um agravante. Este profissional, por sua vez, se vê em situações em que precisa escolher entre o acolhimento, a tolerância ou eventualmente a rejeição a certos elementos da cultura com que tem contato em seu dia a dia. No entanto, o modelo que prevalece em sala de aula ainda é o da assimilação. Como afirma Watt (2006):

A abordagem assimilacionista à diversidade cultural e étnica pode ser resumida como "quando em Roma, faça como os romanos, ou sofra as consequências". A abordagem clássica assimilacionista vê a diversidade étnica e cultural como fonte de divisão e de conflito e tende a presumir que os grupos étnicos minoritários são insuficientes e carentes de capital cultural. Esta abordagem promove a absorção de minorias em um sistema de valores "comuns" que era visto como o único caminho a seguir.

Não por um acaso a citação acima reflete a visão francesa sobre a educação ${ }^{3}$. Ela se baseia no paradigma funcionalista da Sociologia da Educação ${ }^{4}$, formulado por Durkheim, e pode ser sintetizado no aforismo da escola igual para todos, herdado da Revolução Francesa, que preconiza que a escola deveria ser única, laica, obrigatória, gratuita e universalizada, sob o encargo do Estado.

Tal abordagem ainda é predominante nas escolas e universidades brasileiras, apesar de as políticas compensatórias, como a lei de cotas e a obrigatoriedade do ensino de Cultura Afro-brasileira e Africana e Cultura Indígena, colocarem em xeque esse paradigma.

\footnotetext{
${ }^{3}$ Sobre a tendência francesa à homogeneização da educação com vistas à assimilação das diferenças, ver, por exemplo, o filme "Entre os Muros da Escola", do diretor Laurent Cantet, 2008.

${ }^{4}$ Tal paradigma vai ser duramente criticado pelos teóricos da Sociologia Crítica, no que ficou conhecido como o paradigma reprodutivista da sociologia da educação. Bourdieu, o principal autor desse grupo, afirma que a escola, ao ignorar desigualdades culturais entre crianças de diferentes classes sociais ao transmitir os conteúdos que opera, bem como seus métodos e técnicas e os critérios de avaliação que utiliza, favorece os mais favorecidos e desfavorece os mais desfavorecidos". Em outras palavras, "tratando todos os educandos, por mais desiguais que sejam de fato, como iguais em direitos e deveres, o sistema escolar é levado a dar sua sanção às desigualdades iniciais diante da cultura" (BOURDIEU, 1998, p. 53).
} 
Sobre a questão da igualdade e da uniformidade de tratamento, Boaventura Souza Santos afirma:

As pessoas e os grupos sociais têm o direito a ser iguais quando a diferença os inferioriza, e o direito a ser diferentes quando a igualdade os descaracteriza [...]. Este é, consabidamente, um imperativo muito difícil de se atingir e manter'. Não se deve contrapor igualdade a diferença. De fato, a igualdade não está oposta à diferença, e sim à desigualdade, e diferença não se opõe à igualdade, e sim à padronização, à produção em série, à uniformidade, a sempre o 'mesmo', à 'mesmice' (BOAVENTURA, 2001, p.10).

Neste caso, é importante lutar ao mesmo tempo contra a homogeneização e a padronização, mas também contra a desigualdade e a discriminação presentes na nossa sociedade, especialmente no ambiente escolar, reconhecendo as diferenças e rechaçando os fenômenos de intolerância, xenofobia e negação do outro.

\section{A “nova imigração" brasileira}

São muitos os trabalhos escritos sobre a socialização dos imigrantes e seus descendentes e também, especificamente, sobre o processo de escolarização ${ }^{5}$, particularmente a partir do estudo pioneiro de Willems, publicado em 1946, a respeito dos imigrantes que chegaram ao Brasil no século XIX, na que ficou conhecida como a "Grande Imigração".

Já o novo fluxo imigratório para o Brasil se caracteriza pela forte presença de latino-americanos, africanos, chineses e coreanos. Este é um fluxo que já tem pelo menos 40 anos. Paiva (2007) assinala que os imigrantes provenientes da América Latina passaram, a partir dos anos 1970, a constituir o maior fluxo de imigração internacional para o Brasil. A partir dos anos 1980, os fluxos latino-americanos se destinaram, principalmente, a duas áreas: as regiões de fronteiras e as regiões metropolitanas (PATARRA, 2002), em especial São Paulo e Rio de Janeiro.

\footnotetext{
${ }^{5}$ Cf. Franco e Sá, 2011; Luchese e Kreutz, 2011, e Fiori, 2003.
} 
O caso mais estudado é o da cidade de São Paulo, onde há um contingente expressivo de famílias imigrantes, trazendo à tona a questão das crianças imigrantes ou a geração 1,5. A geração 1,5 pode ser definida como a geração de filhos dos imigrantes adultos que chegaram ainda crianças no país receptor (KASINITZ, MOLLENKOPF e WATERS, 2004), ou seja, a segunda geração, é-a que já nasceu no país receptor.

Apesar da presença visível desses "novos" imigrantes, tanto na cidade de São Paulo, quanto na região metropolitana do Rio de Janeiro, pouco se conhece sobre esses "novos" brasileiros, sua integração na sociedade abrangente e a maneira como eles são recebidos nas escolas. Algumas dissertações e teses já estão sendo escritas sobre o assunto (YANG, 2011; OLIVEIRA, 2012); é possível que daqui a alguns anos possamos compreender melhor tal processo.

No caso da Baixada Fluminense, encontramos principalmente congoleses e chineses. Os congoleses se concentram no município de Duque de Caxias e preferem frequentar as escolas públicas; os chineses estão concentrados no município de Nova Iguaçu, mas começam a se espalhar pelos municípios vizinhos e são encontrados em escolas particulares ou nas de ensino médio mantidas pelo governo federal.

Casos de xenofobia são relatados por ambos os grupos. Os congoleses, além de sofrerem a xenofobia, são estigmatizados pelo estereótipo do africano como miserável, mas também sofrem muito racismo. Os dois grupos são bastante fechados e pouco estudados, embora se registrem alguns trabalhos em andamento ${ }^{6}$.

$\mathrm{Na}$ nossa pesquisa, apareceu um aluno chinês matriculado em uma escola particular do município de Paracambi. Nesse caso, os conflitos são duplos: do aluno com os colegas de escola, que debocham do seu sotaque, e dos pais com os professores, porque o aluno é canhoto e os pais insistem que a criança deve aprender a escrever com a mão direita.

\footnotetext{
${ }^{6}$ Sobre congoleses ver Petrus e Francalino, 2008 e 2010 e Petrus, 2010; sobre os chineses, Costa, 2014.
} 


\section{A imigração nordestina para o Rio de Janeiro}

Segundo o Censo Demográfico de 2000 (IBGE, 2000), a população brasileira correspondia, naquele ano, a 170 milhões de habitantes. A mobilidade da população no período de 1995 a 2000 (IBGE, 2003) ainda era muito significativa. Em números absolutos, mais de 5 milhões de pessoas se deslocaram internamente neste período, dos quais 40\% dirigiram-se para a Região Sudeste. Além disso, os dados mostram que a população está se tornando cada vez mais urbana: a taxa de urbanização subiu de 75,59\% (em 1991) para $81,23 \%$ (em 2000). Produto desse crescimento foi um aumento na demanda por educação, mais significativamente a destinada a jovens e adultos, sobretudo no meio urbano.

De acordo com Simões:

O século XX marcará uma imensa transformação no território da Baixada Fluminense, transformando-a numa área urbana periférica intimamente ligada à cidade do Rio de Janeiro, podendo ser considerada, sem exageros, como uma extensão desta para além dos seus limites administrativos" (SIMÕES, 2006, p. 81).

Brito (2000) mostra que, após a década de 50 do século $X X$, houve um grande fluxo migratório em direção ao estado do Rio de Janeiro, composto, em grande parte, por migrantes nordestinos. Tais migrantes, que buscavam melhores condições de vida e oportunidades de trabalho promovidas pela industrialização, acabaram ocupando a periferia, especialmente a Baixada Fluminense, já que o Rio de Janeiro não tinha capacidade nem planejamento para absorver esse contingente populacional.

É nesse momento que a Baixada Fluminense se insere como área de expansão do Rio de Janeiro, com a proliferação de loteamentos que oferecem, de um modo geral, moradias a baixo custo e carência de infraestrutura. Segundo Carneiro (2001), a valorização dos loteamentos e a expansão da periferia acontecem com alguma infraestrutura conseguida graças à mobilização da população, já que o estado não demonstrava interesse em a promover. Com isso, os loteamentos próximos se valorizavam, atraindo a população com poder aquisitivo melhor e os proprietários 
dirigiam-se para áreas mais distantes, reproduzindo o mesmo processo (FIGUÊREDO, 2004).

Até 1980, as migrações internas brasileiras apresentavam um mesmo perfil: grandes fluxos que saíam do Nordeste e de Minas Gerais em direção aos estados de São Paulo e Rio de Janeiro. Na década de 70, houve um decréscimo da migração para o Rio de Janeiro e um aumento expressivo para São Paulo. Entre as explicações para a mudança no fluxo estão o impacto da mudança da capital do País para Brasília, o que resultou em um novo fluxo migratório de nordestinos e mineiros para o Centro-Oeste, e um maior crescimento da economia urbano industrial paulista (BRITO, 2000).

Entretanto, no período de 1999 a 2000, o contingente de migrantes que se deslocaram para o estado do Rio de Janeiro atingiu 615 mil pessoas, enquanto que a população total aumentou 1,7 milhão neste mesmo período.

Do total de migrantes instalados no estado do Rio de Janeiro, 7\% chegou há menos de um ano, e $29 \%$, entre um e dois anos. Desta forma, pode-se deduzir que, ao contrário do que o senso comum imagina, a Região Metropolitana do Rio de Janeiro continua a receber migrantes oriundos das mais diversas regiões do país .

\section{A Região Metropolitana Do Río De Janeiro}

Como referencial empírico, foram utilizados os dados de uma pesquisa de abordagem qualitativa, procedendo-se a uma análise aprofundada de um dado ambiente com vistas a contribuir para melhor se conhecer a realidade de uma sociedade. Assim, buscou-se analisar escolas de ensino fundamental no município de Nova Iguaçu, na Baixada Fluminense, região metropolitana do Rio de Janeiro.

Esta região foi criada pela Lei Complementar Federal $n^{\circ}$ 20, em $1^{\circ}$ de julho de 1974, que funde os estados da Guanabara e do Rio de Janeiro. Atualmente, é composta por 19 municípios, abrangendo $12 \%$ da área do estado. Todavia, sua composição ainda é bastante desequilibrada em relação ao município do Rio de Janeiro, apresentando 50\% do produto interno bruto - PIB do estado - e 69\% do PIB da Região Metropolitana do Rio de Janeiro. 
Em termos populacionais, o fenômeno se repete. Segundo o censo de 2010, a Região Metropolitana do Rio de Janeiro possui 11.835.708 habitantes, o que corresponde a $74 \%$ do total da população do estado. No município do Rio de Janeiro, concentra-se $53 \%$ da população da RMRJ.

A região da Baixada Fluminense está entre as regiões mais pobres do País. Sua população atual é estimada em aproximadamente 3,7 milhões habitantes (IBGE, 2010), distribuídos nos 13 municípios que compõem a região: Belford Roxo, Duque de Caxias, Guapimirim, Itaguaí, Japeri, Magé, Mesquita, Nilópolis, Nova Iguaçu, Paracambi, Queimados, São João de Meriti e Seropédica.

Os indicadores de educação, longevidade e renda que compõem o índice de desenvolvimento humano (IDH), adotado pelo Programa das Nações Unidas para o Desenvolvimento (PNUD), mostram que essa região apresenta um baixo desenvolvimento econômico e escolar. O IDH médio é de aproximadamente 0,755, o que representa um desenvolvimento moderado. Já o índice de desenvolvimento infantil (IDI), instrumento que contribui para a formulação e o monitoramento de políticas públicas orientadas à infância, criado em 2001, e que incorpora variáveis como a oferta de serviços de saúde e educação e de cuidado e proteção da família às crianças nos seis primeiros anos de vida, a região tem um índice de aproximadamente 0,672, bem distante do mínimo aceitável que, de acordo com o Fundo das Nações Unidas para a Infância, é de o,8 (UNICEF, 2005).

\section{O trabalho empírico com filhos de migrantes}

Os dados para esta pesquisa foram coletados com a observação participante e com entrevistas semiestruturadas, direcionadas a alunos, professores e demais funcionários de duas escolas de ensino médio: uma, de ensino fundamental e outra, de educação infantil em um município da Baixada Fluminense, na Região Metropolitana do Rio de Janeiro.

Inicialmente, seria realizada apenas uma pesquisa prospectiva em uma escola municipal de ensino fundamental para testar as perguntas e as hipóteses e desenhar a 
amostra. Uma casualidade acabou nos levando a estender a pesquisa à escola de educação infantil e às escolas públicas de ensino médio (estaduais e federais), localizadas na região. Nas escolas de ensino fundamental e de educação infantil, foram entrevistados principalmente professores e funcionários. Priorizaram-se o levantamento de dados e a observação participante. Nas escolas de ensino médio, o maior número de entrevistas foi realizado com os alunos.

As entrevistas ajudam no registro e análise sobre os sujeitos na escola, abordando sexo, idade, religião, formação, tempo de atuação na área de educação, função na escola e questões ligadas a currículo escolar e manifestações culturais diversas na escola, em contato com os valores dos entrevistados. São dados que ainda estão sendo tabulados e analisados.

O número total de alunos atendidos pela escola de ensino fundamental que examinamos, situada em uma região periférica do município de Nova Iguaçu, é de 337, distribuídos em turmas que vão da educação infantil ao $5^{\circ}$ ano. Destes, apenas 17 não são naturais do estado do Rio de Janeiro, o que corresponde a 0,5\% do total. Estes alunos migrantes são: 8 de Minas Gerais, 3 de São Paulo, 2 de Belém do Pará, 1 do Ceará, 1 do Maranhão, 1 do Espírito Santo e 1 do Acre. Em números absolutos, são poucos, mas, se analisarmos as porcentagens, verificaremos que o fenômeno não é desprezível. Com certeza, o aprofundamento da pesquisa com entrevistas e o levantamento das origens regionais dos pais das crianças deverão atribuir maior relevância às migrações.

$\mathrm{Na}$ nossa amostra aleatória, houve um aumento de 30\% de filhos de migrantes matriculados nas escolas municipais de Nova Iguaçu no ano de 2013. Acreditamos que esse aumento possa ser reflexo do crescimento da construção civil no estado do Rio de Janeiro (obras para a Copa do Mundo de 2014, Olimpíadas de 2016, Plano de Aceleração de Crescimento - PAC).

As questões que envolvem a cultura local e o contato com pessoas migrantes se refletem bastante em sala de aula. Em uma das classes pesquisadas, há alguns migrantes e filhos de migrantes, oriundos principalmente da Região Nordeste do Brasil. Esta é uma região que, apesar de muito procurada para turismo, em função do 
clima ameno e das praias belíssimas, se caracteriza por muitos índices negativos: alta mortalidade infantil, baixo nível de escolaridade e baixa renda. Isto faz com que os migrantes nordestinos e seus filhos sejam estigmatizados.

Muitas vezes, a estigmatização se estende à cultura nordestina. Igualmente dignos de nota são episódios em que crianças oriundas da Região Nordeste são discriminadas por seu sotaque ou pela utilização de palavras que não são comuns na Região Sudeste. Exemplos recorrentes são os casos de crianças que pedem para ir à “casinha”, ao invés de pedir para usar o banheiro, ou, quando se referem aos pais, usam termos como "mainha" e "painho", quando a praxe no Sudeste do País é dizer mãe e pai. Tais casos sempre rendem muita zombaria e acusações. "Fulano não sabe falar direito", ou, “Fulano fala estranho”. São frases bastante repetidas em tais ocasiões.

Um aluno do terceiro ano do ensino médio de uma escola federal declara que ao chegar ao município de Nova Iguaçu, transferido do município de Natal no Rio Grande do Norte, logo foi apelidado de "paraíba”, “cabeça de rapadura”, “comedor de calango e "etíope brasileiro". As provocações partiam dos alunos, mas os professores não interferiam e, na maioria das vezes, fingiam que não percebiam o que estava acontecendo.

Caso mais grave foi o de um aluno, transferido de Manaus para a mesma escola, que sofreu preconceito em função do estereótipo que alunos e professores tinham da região amazônica. Chegou a discutir em sala com o professor de geografia que afirmou que em Manaus jacarés e sucuris passeavam dentro das casas.

No entanto, há também um tipo de migração pouco mapeada, de certa forma pendular. Algumas famílias de migrantes estabelecem-se no Rio de Janeiro por alguns anos e, em caso de desemprego, retornam ao estado de origem; passado algum tempo, retornam ao estado do Rio de Janeiro. Em alguns casos, as crianças fazem sozinhas essas migrações temporárias, sendo enviadas de volta, por exemplo, para fazer companhia a uma avó doente, para se afastar de más companhias, ou porque os pais se separaram e a 
mãe não tem com quem deixar os filhos enquanto trabalha. ${ }^{7}$ Nesses casos, acabam tendo problemas tanto nas escolas de seu estado de origem quanto nas de destino.

Uma das alunas relata que o pai, baiano, resolveu voltar para seu estado natal quando ela estava na segunda série do ensino fundamental. Ela precisou reaprender o alfabeto. "Lá eles falam fê, mê, ipsilone ..." e foi apelidada de carioquinha. Quando retornou ao Rio de Janeiro, sofreu o processo inverso: foi chamada de baianinha e novamente reaprendeu o alfabeto. Outro problema recorrente é o fato de todos os alunos nordestinos serem chamados de "paraíbas", independentemente da sua real origem estadual. Ou seja, a escola não cumpre seu papel de valorizar as diferentes culturas e contribuir para que os alunos tenham orgulho de suas origens culturais; pelo contrário, reafirma cada vez mais sua postura homogeneizadora e universalista e reforça as diferenças regionais, inclusive quanto às diferenças de capital cultural.

Como Freire afirmou:

Muita gente já deve ter dito o que vou dizer agora. Percebi quão fortes são as nossas marcas culturais. Mas quão mais fortes elas se tornam na medida em que não as idealizamos. Na verdade, no momento em que começas a dizer: não, tudo o que é bom, só é chileno, as marcas da tua cultura enfraquecem. Mas, na medida em que, em lugar da idealização das tuas marcas, tu as tratas bem, cuidas delas seriamente, sem absolutizá-las, então percebes que, sem elas, te seria difícil, inclusive, receber outras marcas que, ao lado de tua história pessoal, fossem significativas (FREIRE; FAUNDEZ, 1985, p. 17).

No entanto, o fato de sua cultura ser altamente desvalorizada pela sociedade abrangente faz com que, ao contrário do que afirma Freire, os descendentes de migrantes nordestinos e mineiros que chegam à Baixada Fluminense façam questão de se declarar cariocas, envergonhando-se, muitas vezes, do sotaque e da cultura de seus pais. Neste ponto, são radicalmente diferentes dos descendentes de imigrantes italianos e

\footnotetext{
${ }^{7}$ Sobre esse tipo de circulação de crianças, ver Fonseca,1999.
} 
alemães, localizados no Sul do Brasil, que fazem questão de manter sua cultura e reafirmar uma identidade diferenciada da sociedade abrangente ${ }^{8}$.

\section{Considerações finais}

Sem dúvida, pluralidade vive-se, ensina-se e aprende-se. É trabalho de construção, no qual o envolvimento de todos se dá pelo respeito e pela própria constatação de que, sem o outro, nada se sabe sobre ele, a não ser o que a própria imaginação fornece (BRASIL, 1998, p. 141).

Diante de todos os dados descritos, acreditamos que o presente trabalho poderá contribuir na reflexão a respeito da práxis que envolve a própria subjetividade dos diversos sujeitos envolvidos na escola e, também, para melhor compreender as relações destas múltiplas identidades no cotidiano da escola.

Esperamos contribuir para melhorar a prática docente diante da pluralidade cultural em que se insere este profissional na atualidade. Tal pluralidade pode ser marcada por muitos conflitos de interesses e por divergências. A reflexão acerca das posturas adotadas e o olhar do outro sobre a prática em sala de aula podem contribuir para um enriquecimento cultural e para atitudes mais tolerantes e acolhedoras das diferenças de pensamento, cruzando as fronteiras disciplinares. Esperamos, igualmente, contribuir para uma discussão, cada vez mais atual, sobre a relevância e os sentidos das migrações.

\footnotetext{
${ }^{8}$ Sobre esse assunto, ver Santos, 2010, ou Santos e Zanini, 2010.
} 


\section{Referências}

ANDRÉ, Bianka Pires. De la integración deseada a la integración vivida: la experiencia de adolescentes brasileños en escuelas de Barcelona. 2007. Tese (Doutorado em......) Universidad de Barcelona, 2007. Disponível em: http://www.tesisenxarxa.net/TDX0604108-111625/index.html

BOURDIEU, Pierre. Escritos de educação. Petrópolis: Vozes, 1998.

BOURDIEU, Pierre. O desencantamento do mundo. São Paulo, 1979

BRASIL, Secretaria de Educação Fundamental. Parâmetros Curriculares Nacionais: temas transversais terceiro e quarto ciclos. Brasília: MEC/SEF, 1998.

BRITO, Fausto. Brasil, final de século: a transição para um novo padrão migratório? In: Anais da ABEP, 2000, Caxambu, 2000.

BRUSCHINI, Cristina.; AMADO, Tina. Estudos sobre mulher e educação. Cadernos de Pesquisa. São Paulo, n. 64, p. 4-13, fev. 1988.

CANCLINI, Nestor Garcia Culturas híbridas. Rio de Janeiro: Editora da UFRJ, 1999.

CANDAU, Vera Maria (Org.). Sociedade, educação e cultura(s): questões e propostas. Petrópolis, RJ: Vozes, 2002.

CANEN, Ana. Educação multicultural, identidade nacional e pluralidade cultural: tensões e implicações curriculares. Cadernos de Pesquisa, n. 111, p. 135-150, 2000.

CANEN, Ana. Universos culturais e representações docentes: subsídios para a formação de professores para a diversidade cultural. In: Educação e Sociedade, n 77, p. 207-227, 2001.

CANEN, Ana.; XAVIER, Giseli Pereli de Moura.Formação continuada de professores para a diversidade cultural: ênfases, silêncios e perspectivas. In: Revista Brasileira de Educação v. 16 n. 48 set.-dez. 2011

CANEN, Ana; MOREIRA, Antônio Flávio Barbosa, Reflexões sobre o multiculturalismo na escola e na formação docente. In: CANEN, Ana.; MOREIRA, Antônio Flávio Barbosa., (Orgs.). Ênfases e omissões no currículo. São Paulo: Papirus. p. 15-43, 2001.

CANTET, Laurent. Entre os muros da escola ("entre les murs"). Haut et Court, França, 2008. 
CATANI, Denice et al. História, memória e autobiografia da pesquisa educacional e na formação. in: CATANI, Denice et al. (Org.). Docência, memória e gênero: estudos sobre formação. São Paulo: Escrituras Editora, 1997.

CLAPARÈDE, E. A escola sob medida. 3. ed. Rio de Janeiro: Fundo de Cultura, 1973

COSTA, Edivan de Azevedo Silva. Da China ao Brasil: uma análise da imigração chinesa no município de São Gonçalo (RJ). 2014. Trabalho de Conclusão de Curso (Graduação em Geografia) - Universidade do Estado do Rio de Janeiro, 2014.

CUCHE, Denys. A noção de cultura nas ciências sociais. Bauru: EDUSC, 1999.

DUBAR, C. A socialização: construção de identidades sociais e profissionais. Porto: Porto Ed.,1997.

FERREIRA, Ademir Pacelli . O Migrante na rede do outro. Rio de Janeiro, Te Corá, 1999.

FERREIRO, Emilia. Diversidad y proceso de alfabetización. De la celebración a la toma de conciencia, en pasado y presente de los verbos leer y escribir. Buenos Aires, Argentina: Fondo de Cultura Económica. Buenos Aires, Argentina. 2001

FIGUERÊDO, Maria Aparecida de. Gênese e (re)produção do espaço da Baixada Fluminense. Revista geo-paisagem Ano 3, n 5, Janeiro/Junho de 2004.

FIORI, Neide Almeida (Org.). Etnia e educação: a escola "alemã” do Brasil e estudos congêneres. Florianópolis/Tubarão: UFSC/Unisul, 2003.

FONSECA, Claudia. Quando cada caso não é um caso: pesquisa etnográfica e educação. In: Rev. Bras. Educ. [online]. n. 10, p. 58-78, 1999.

FRANCO, Sebastião P. e SÁ, Nicanor Palhares Gênero, etnia e movimentos sociais na história da educação. Vitória: EDUFES, 2011.

FREIRE, Paulo; FAUNDEZ, Antônio. Por uma pedagogia da pergunta. 3. ed. Rio de Janeiro: Paz e Terra, 1985.

GRANT, Nigel. Multicultural education in Scotland. Edinburgh: Dunedin Academic Press, 2000.

GUSMÃO, Neusa Maria Mendes. Os filhos da África em Portugal: antropologia, multiculturalidade e educação. Belo Horizonte: Autêntica, 2005. 
HALL, Stuart. Da diáspora. Belo Horizonte: Editora UFMG, 2003.

HALL, Stuart. A identidade cultural na pós-modernidade. Rio de Janeiro: DP\&A, 2006.

HYPOLITO, Alvaro Moreira. Trabalho docente, classe social e relações de gênero. Campinas, Papirus, 1997.

IBGE. Censo demográfico. Rio de Janeiro, 2000.

LEITE, Dante. Moreira. O caráter nacional brasileiro: história de uma ideologia, 4. ed., São Paulo: Pioneira, 1983.

LUCHESE, Terciane Ângela; KREUTZ, Lúcio (Orgs.). Imigração e educação no Brasil: histórias, práticas e processos escolares. Santa Maria: UFSM, 2011.

KASINITZ , P; MOLLENKOPF, J. H.; WATERS, M. C. "Worlds of the second generation" In: KASINITZ, P; MOLLENKOPF, J. H.; WATERS, M. C. Becoming New Yorkers: ethnographies of the new second generation. New York: Russell Sage Foundation, 2004.

KONDER, Leandro. Marx e a Sociologia da Educação. In: TURA, Maria de Lourdes Rangel (Org.). Sociologia para educadores, 4. ed., Rio de Janeiro: Quartet, 2006.

KOSMINSKY, E.V. Memórias da Infância: as Filhas de imigrantes judeus no Brasil. Cadernos CERU, São Paulo, n. 11, p. 47-63, 2000.

MCLAREN, P. Multiculturalismo revolucionário: pedagogia do dissenso para o novo milênio. Porto Alegre: Artes Médicas, 2000.

OLIVEIRA, Gabriela Camargo de. A segunda geração de bolivianos na cidade de São Paulo. Dissertação de Mestrado em Demografia.Instituto de Filosofia e Ciências Humanas. Universidade estadual de Campinas, 2012.

PAIVA, Odair da Cruz . Migrações e Nova Fronteira Utópica. In: Odair da Cruz Paiva. (Org.). Migrações Internacionais. Desafios para o Século XXI. 1 ed. São Paulo: Memorial do Imigrante, 2007, v. 1, p. 11-28.

PATARRA, Nide. "Migrações internacionais e integração econômica no cone Sul: notas para discussão" In: SALES, T.; SALLES, M. do R. R. (orgs). Políticas migratórias: América Latina, Brasil e brasileiros no exterior. São Carlos: EdUFSCar, Editora Sumaré, 2002. 
PETRUS, Maria Regina; FRANCALINO, João Henrique. Dinâmicas de afirmação e ressignificação de identidades: um projeto cultural em construção com refugiados e imigrantes congoleses e angolanos. REMHU, ano XVI, n. 31, p.00-00, 2008.

PETRUS, Maria Regina; FRANCALINO, João Henrique. Refugiados congoleses no Rio de Janeiro: afirmação e (re)significação de identidades nas dinâmicas de inserção social. In: FERREIRA, A. P.;et al. (Orgs.). A experiência migrante: entre deslocamentos e reconstruções. Rio de Janeiro: Garamond, 2010.

PETRUS, Maria Regina. Refugiados congoleses no Rio de Janeiro e dinâmicas de "integração local": das ações institucionais e políticas públicas aos recursos relacionais das redes sociais. 2010. Tese (Doutorado em Planejamento Urbano e Regional) - Instituto de Pesquisa e Planejamento Urbano e Regional /Universidade Federal do Rio de Janeiro, Rio de Janeiro, 2010.

SANTOS, Boaventura Sousa. As tensões da Modernidade. Fórum Social Mundial, Biblioteca das alternativas, 2001 (http://www.forumsocialmundial.org.br).

SANTOS, Miriam de O. A noção de identidade e seu uso nos estudos migratórios. REMHU. Brasília, v. 28, p. 27-43, 2010.

SANTOS, Miriam de Oliveira. e ZANINI, Maria Catarina Chitolina. As memórias da Imigração no Rio Grande do Sul. Mneme (Caicó. Online), v. 11, p. 25-35, 2010.

SAYAD, Abdelmalek.. A Migração ou os paradoxos da alteridade. São Paulo: Editora da Universidade de São Paulo,1998.

SEMPRINI, Andréa. Multiculturalismo. Bauru: EDUSC, 1999.

SILVA, Tomaz Tadeu da. A produção social da identidade e da diferença. In: SILVA, Tomaz Tadeu da (Org.). Identidade e diferença: a perspectiva dos estudos culturais. Petrópolis: Vozes. 2000. p. 73-102.

SIMÕES, Manoel Ricardo. A Cidade estilhaçada: reestruturação econômica e emancipações municipais na baixada fluminense. 2006. Tese (Doutorado em......) Programa de Pós-Graduação em Geografia do Departamento de Geografia do Instituto de Geociências, Universidade Federal Fluminense (UFF), Niterói, 2006.

SCHÜTZ, Alfred. Collected Papers II. Studies in Social Theory. The Hague: Martinus Nijhoff,1971. 
UNESCO. Declaração Universal sobre a Diversidade Cultural. 2001. Disponível em: <http://unesdoc.unesco.org/images/0012/001271/12716opor.pdf.> Acesso em: 3 maio de 2012.

YANG, Eun Mi. A "geração 1.5" dos imigrantes coreanos em São Paulo: identidade, alteridade e educação. 2011.Tese (Doutorado em.....) - Programa de Pós-Graduação em Educação - USP, São Paulo, 2011.

WATT, Philip. An Intercultural Approach to 'integration',Translocations: The Irish Migration, Race and Social Transformation Review. v. 1, Issue 1 (Autumn 2006).

WILLEMS, Emilio. A Aculturação dos alemães no Brasil: estudo antropológico dos imigrantes alemães e seus descendentes no Brasil. 1. ed. São Paulo: Nacional, 1946. 
Recebido em: 08/03/2014 Aprovado em: 22/05/2014

Universidade do Estado de Santa Catarina - UDESC

Centro de Ciências Humanas e da Educação - FAED

Revista PerCursos

Volume 15 - Número 28 - Ano 2014 revistapercursos@gmail.com 